\title{
Hyperoside decreases the apoptosis and autophagy rates of osteoblast MC3T3-E1 cells by regulating TNF-like weak inducer of apoptosis and the p38mitogen activated protein kinase pathway
}

\author{
QING ZHANG $^{1}$ and XIAO-FENG ZHANG ${ }^{2}$
}

${ }^{1}$ Division of Hand and Foot Surgery, Department of Orthopedics; ${ }^{2}$ Department of Central Pharmacy, Huai'an Second People's Hospital, The Affiliated Huai'an Hospital of Xuzhou Medical University, Huai'an, Jiangsu 223002, P.R. China

Received May 5, 2017; Accepted April 6, 2018

DOI: $10.3892 / \mathrm{mmr} .2018 .9622$

\begin{abstract}
Wear particles generated between the interface of joints and artificial joint replacements are one of the primary causes of aseptic loosening. The aim of the present study was to investigate the influence of titanium (Ti) particles on the apoptosis and autophagy of osteoblasts, and probe into the potential use of hyperoside (Hy) as a protector for osteoblasts in Ti particle-induced injury. MC3T3-E1 cells were divided into control, $\mathrm{Ti}, \mathrm{Hy}-1+\mathrm{Ti}$ and $\mathrm{Hy}-2+\mathrm{Ti}$ groups. Cell viability was detected using a Cell Counting Kit-8 assay. Apoptosis and autophagy rates were determined using flow cytometry. Expression levels of apoptosis-associated genes, including caspase-3, apoptosis regulator BAX, apoptosis regulator Bcl-2 and cellular tumor antigen p53, in addition to autophagy-associated genes, including Beclin1 and microtubule-associated protein light chain 3 conversion LC3-II/I, were measured using reverse transcription-quantitative polymerase chain reaction and western blotting. Activation of the tumor necrosis factor ligand superfamily member 12 (TWEAK)-mitogen activated protein kinase 11 (p38) mitogen activated protein kinase (MAPK) pathway was observed by western blotting. The present study demonstrated that pretreatment with Hy was able to increase cell viability and proliferation, and decrease apoptosis and autophagy to protect MC3T3-E1 cells against Ti particle-induced damage. Activation of the TWEAK-p38 pathway contributed to the repair processes of treatment with Hy. The present results suggested that Hy protected osteoblasts against Ti particle-induced damage by regulating the
\end{abstract}

Correspondence to: Dr Xiao-Feng Zhang, Department of Central Pharmacy, Huai'an Second People's Hospital, The Affiliated Huai'an Hospital of Xuzhou Medical University, 62 South Huaihai Road, Huai'an, Jiangsu 223002, P.R. China

E-mail: wxz96585@126.com

Key words: hyperoside, MC3T3-E1 cells, apoptosis, autophagy, tumor necrosis factor-like weak inducer of apoptosis, p38 mitogen activated protein kinase
TWEAK-p38 pathway, which suggested the potential of Hy as a protective agent for bones.

\section{Introduction}

Numerous wear particles exist in the interface membranes between bone and artificial joints, which has been associated with osteolysis in numerous animal models and may induce the inflammatory reaction of macrophages in vitro $(1,2)$. Lochner et al (3) discovered that apoptotic rates were increased in osteoblasts exposed to pure titanium (Ti) particles, titanium oxide, polymethylmethacrylate and particulate zirconium oxide. Piao et al (4) recently reported that Ti particles induced osteogenic inhibition and bone destruction.

Hyperoside (Hy), a flavonoid glycoside compound extracted from plants, is widely found in the fruits and herbs of a number of different plant families, including Hypericaceae, Rosaceae, Campanulaceae, Ericaceae and Labiatae (4,5). Protective effects of Hy against liver damage, depression, inflammation, thrombus, oxidative stress, apoptosis and cancer have been documented in previous studies (6-9). Recently, Zhang et al (10) reported that Hy inhibited the phosphorylation of transcription factor $\mathrm{p} 65 /$ nuclear factor $(\mathrm{NF})-\kappa \mathrm{B}$, mitogen activated protein kinase (MAPK; including p38 MAPKs, MAPK 8, MAPK 1 and MAPK 3) activated transcription factor 3 protein expression, and additionally suppressed apoptosis regulator BAX (Bax), cytochrome c, caspase-9 and caspase-3 in the liver tissues of diabetic mice.

Tumor necrosis factor ligand superfamily member 12 (TWEAK) is a transmembrane protein composed of 249 amino acids and located at 17p13 of the chromosome (11). As a member of the tumor necrosis factor (TNF) superfamily, TWEAK is a TNF family ligand expressed in numerous human tissues $(12,13)$. Previous studies demonstrated that TWEAK exerts a variety of biological effects, including releasing pro-inflammatory cytokines, mediating immunoreactions, promoting apoptosis, and regulating the repair and regeneration of tissues in combination with its receptor $(14,15)$. TWEAK was able to activate the classical NF- $\kappa B$ signaling pathway and the non-classical NF- $\kappa \mathrm{B}$ and MAPK pathways (16-18). With high conservation, the MAPK signaling pathways extensively exist in cells, functioning as a transmitter 
of stimulatory signals from the outside to the inside of the cell to induce a series of biological responses (19). p38 MAPK is a classical MAPK pathway. In the presence of environmental stimuli or stimulating factors, including TNF- $\alpha$, TWEAK, interleukin-1 and ischemia/reperfusion, extracellular signals of p38 MAPK specifically bind with receptors to promote apoptosis, differentiation, migration, infiltration or inflammation (20-22).

Apoptosis and autophagy have dual roles; they exert protective effects when subjected to short and moderate-intensity levels of cell stress, and induce cell death when excessive (23). The present study aimed to investigate the effects of Hy on the apoptosis and autophagy of osteoblasts exposed to Ti particles, and examine whether TWEAK and p38 MAPK are involved in the mechanism.

\section{Materials and methods}

Cell culture. MC3T3-E1 cells were purchased from National Infrastructure of Cell Line Resource (Beijing, China), cultured in $\alpha$-minimum essential medium (Thermo Fisher Scientific, Inc., Waltham, MA, USA) containing $10 \%$ fetal calf serum (Shanghai Macklin Biochemical Co., Ltd., Shanghai, China), and incubated in a $5 \% \mathrm{CO}_{2}$ incubator at $37^{\circ} \mathrm{C}$.

Immunocytochemical staining. Cells were seeded at a density of $3 \times 10^{4}$ cells $/ \mathrm{ml}$ on sterilized glass coverslips. Following fixation for $10 \mathrm{~min}$ with $1 \mathrm{ml} /$ well Immunol Staining Fix Solution (Beyotime Institute of Biotechnology, Haimen, China) at room temperature, the coverslips were soaked in $0.75 \% \mathrm{H}_{2} \mathrm{O}_{2}$-PBS for $10 \mathrm{~min}$ at $4^{\circ} \mathrm{C}$ to block. The slides were incubated overnight with primary anti-OPG antibody (1:100; Santa Cruz Biotechnology, Inc., Dallas, TX, USA; polyclonal goat antibody n-20; cat. no. sc:8468), diluted in $1 \%$ bovine serum albumin (Thermo Fisher Scientific, Inc.). Subsequent to returning to room temperature and being washed, the slides were incubated with biotinylated secondary antibodies [goat anti-rabbit immunoglobulin (Ig)G-B; cat. no. sc-2040; rabbit anti-goat IgG-B; cat. no. sc-2774; 1:100; Santa Cruz Biotechnology, Inc.] for $1 \mathrm{~h}$ at room temperature. A streptavidin-biotin-peroxidase complex (ABC kit; Vectastain; Vector Laboratories, Inc., Burlingame, CA, USA) was subsequently added for $30 \mathrm{~min}$ at room temperature, followed by chromogen 3,3'diaminobenzidine tetrahydrochloride hydrate (Sigma-Aldrich; Merck KGaA, Darmstadt, Germany), added with $3 \%$ hydrogen peroxide in PBS for $1 \mathrm{~min}$ at room temperature. The slides were counterstained with Harris' hematoxylin at room temperature for $2 \mathrm{~min}$. The analysis was conducted using the Axio Imager M1 light microscope (Zeiss AG, Oberkochen, Germany) with magnification, x200.

Grouping. Concentrations of 0.1 and $1 \mathrm{mg} / \mathrm{ml}$ of Ti (Beijing Yannuo Xincheng Technology Co., Ltd., Beijing, China) were firstly used to treat MC3T3-E1 cells for $24 \mathrm{~h}$ at room temperature. To investigate the effects of Hy (Nanjing Daofufu Biotechnology Co., Ltd., Jiangsu, China) on cell viability, apoptosis, autophagy and expression levels of associated genes, the MC3T3-E1 cells were divided into four groups: Control group; Ti group; Hy-1+Ti group; and $\mathrm{Hy}-2+\mathrm{Ti}$ group. In the Hy-1+Ti group and the Hy-2+Ti group, cells were pretreated with 200 and $400 \mu \mathrm{g} / \mathrm{ml} \mathrm{Hy}$ at room temperature, respectively, for $6 \mathrm{~h}$, and subsequently treated with $1 \mathrm{mg} / \mathrm{ml}$ Ti particles for $12 \mathrm{~h}$. In the Ti group, cells were treated with $1 \mathrm{mg} / \mathrm{ml} \mathrm{Ti}$ particles for $12 \mathrm{~h}$ for the following experiments. Cells were treated with anisomycin $(60 \mu \mathrm{M}$ for $1 \mathrm{~h}$ at room temperature; MedChemExpress USA, Monmouth Junction, NJ, USA) to verify the role of the MAPK pathway.

Cell counting kit-8 (CCK-8) assay. Cell viability in each group was detected using a CCK-8 assay (Beyotime Institute of Biotechnology). Cells were grouped and seeded in 96-well plates at a density of $3 \times 10^{4}$ cells $/ \mathrm{ml}$, and subsequently incubated at $37^{\circ} \mathrm{C}$ in a $5 \% \mathrm{CO}_{2}$ incubator for $4 \mathrm{~h}$. Following the addition of $10 \mu \mathrm{lCCK}-8$ reagent to each well, cells were placed into a $5 \% \mathrm{CO}_{2}$ incubator at $37^{\circ} \mathrm{C}$ for $2 \mathrm{~h}$. Optical density values of each group were measured at $450 \mathrm{~nm}$ using a spectrophotometer (Sigma-Aldrich; Merck KGaA).

Flow cytometry (FCM). Cells in the logarithmic phase were collected and incubated in 6-well plates at a density of $1 \times 10^{5}$ cells/well. Cells were digested with EDTA-free trypsin (Beyotime Institute of Biotechnology), stained with Annexin V-fluorescein isothiocyanate and propidium iodide (MedChem Express LLC, Monmouth Junction, NJ, USA), and incubated in a dark place for $15 \mathrm{~min}$ at room temperature. The apoptosis rates of each group were detected using a flow cytometer (EPICS XL-MCL FCM; Beckman Coulter, Inc., Brea, CA, USA) with an excitation wavelength of $488 \mathrm{~nm}$ and an emission wavelength of $530 \mathrm{~nm}$. Data was analyzed using FCS Express version 3.0 (De Novo Software, Glendale, CA, USA).

Cells were treated for $2 \mathrm{~h}$ with the lysosomal inhibitors E64d and pepstatin A (10 mg/ml; MedChemExpress USA) or dimethyl sulfoxide (DMSO) following transfection. Monodansylcadaverine (MDC) powder was purchased from Sigma-Aldrich; Merck KGaA and dissolved in DMSO at $0.1 \mathrm{~mol} / \mathrm{l}$ of the stock concentration. The working concentration was $50 \mu \mathrm{m} / 1$. The cells were incubated with the MDC dye for $45 \mathrm{~min}$ in the dark at $4^{\circ} \mathrm{C}$. The cells were subsequently washed with PBS three times. The positive rate of autophagy was determined using a flow cytometer (EPICS XL-MCL FCM; Beckman Coulter, Inc.). Data was analyzed using FCS Express version 3.0 (De Novo Software, Glendale, CA, USA).

Reverse transcription-quantitative polymerase chain reaction (RT-qPCR). Expression levels of caspase-3, Bax, apoptosis regulator Bcl-2 (Bcl-2), cellular tumor antigen p53 (p53), Beclin1 and microtubule-associated protein light chain 3 conversion (LC3-II/I) mRNA were detected using RT-qPCR. Cells were seeded in 6-well plates at a density of $2 \times 10^{6}$ cells/well. Total RNA was extracted with TRIzol ${ }^{\circledR}$ (Thermo Fisher Scientific, Inc.) according to the manufacturer's protocol. The concentration of extracted RNA was read using an ultraviolet spectrophotometer (Thermo Fisher Scientific, Inc.). cDNA was synthesized by RT with the Takara PrimeScript RT kit (Takara Bio, Inc., Otsu, Japan) at $37^{\circ} \mathrm{C}$ for $60 \mathrm{~min}, 85^{\circ} \mathrm{C}$ for $5 \mathrm{~min}$ and $4^{\circ} \mathrm{C}$ for 5 min. Quantification of mRNA was performed using a TaqMan Gene Expression Assay (Thermo Fisher Scientific, Inc.). PCR was conducted by activating the DNA polymerase at $95^{\circ} \mathrm{C}$ for $10 \mathrm{~min}$, followed by 40 cycles of two-step PCR $\left(95^{\circ} \mathrm{C}\right.$ for $15 \mathrm{sec}$ and $60^{\circ} \mathrm{C}$ for $45 \mathrm{sec}$ ), a final extension at $75^{\circ} \mathrm{C}$ for $10 \mathrm{~min}$ 
and holding at $4^{\circ} \mathrm{C}$. GAPDH was applied as the internal control to normalize the other mRNA expression levels. The following primers in the present study were designed by Sangon Biotech Co., Ltd. (Shanghai, China): Forward 5'-AGAGCTGGACTG CGGTATTG-3' and reverse, $\approx 5$ '-CCATGACCCGTCCCTTGA AT-3' for caspase-3 (product: $145 \mathrm{bp}$ ); forward, 5'-TGGCGA TGAACTGGACAACA-3' and reverse, 5'-CACGGAAGAAGA CCTCTCGG-3' for Bax (product: $86 \mathrm{bp}$ ); forward, 5'-TTCTTT CCCCGGAAGGATGG-3' and reverse, 5'-AGTATCCCACTC GTAGCCCC-3' for Bcl-2 (product: $112 \mathrm{bp}$ ); forward, 5'-ATG AGCGTTGCTCTGATGGT-3' and reverse, 5'-GGTGGCTCA TACGGTACCAC-3' for p53 (product: $133 \mathrm{bp);} \mathrm{forward,} \mathrm{5'-AAC}$ CCCATGCTGTCCTTTCC-3' and reverse, 5'-CAACTG TGTGCCACAAGCATC-3' for Beclin1 (product: $171 \mathrm{bp}$ ); forward, 5'-TCTGAGTCA AGAGGAGGGGT-3' and reverse, 5'-ATCTCTGCCTAATCCACCCG-3' for LC3-I (product: $113 \mathrm{bp}$ ); forward, 5'-TCCCAAGAAACCTTCGGC TT-3' and reverse, 5'-CCAGGACTTGGTATGCTGGC-3' for LC3-II (product: $185 \mathrm{bp}$ ) and forward, 5'-GGCTCATGACCA CAGTCCAT-3' and reverse, 5'-ACATTGGGGGTAGGAACA CG-3' for GAPDH (product: 202 bp). Each reaction was run in triplicate. The quantification of gene expression data was analyzed using the $2^{-\Delta \Delta \mathrm{Cq}}$ method (24).

Western blotting. Cells were incubated in 6-well plates at a density of $2 \times 10^{6}$ cells/well, and grouped. Cells were harvested and washed twice with PBS, and lysed in ice-cold radioimmunoprecipitation assay buffer (Shanghai Yeasen Biotechnology Co., Ltd., Shanghai, China) with freshly mixed $0.01 \%$ phenylmethanesulfonyl fluoride as a protease inhibitor (Shanghai Macklin Biochemical Co., Ltd.), and subsequently incubated for $30 \mathrm{~min}$ on ice. Cell lysates were centrifuged at $10,000 \mathrm{x} \mathrm{g}$ for $5 \mathrm{~min}$ at $4^{\circ} \mathrm{C}$; supernatants containing 20-30 $\mu \mathrm{g}$ protein were collected, and protein concentration was determined using a bicinchoninic acid kit (Thermo Fisher Scientific, Inc.) Samples $(20 \mu \mathrm{g} /$ lane) were run on $10 \%$ SDS-PAGE gels and electrophoretically transferred to nitrocellulose membranes (Thermo Fisher Scientific, Inc.). To block the non-specific proteins, $5 \%$ fat-free milk was incubated with the membranes for $2 \mathrm{~h}$ at room temperature. Membranes were incubated with the following primary specific antibodies at $4^{\circ} \mathrm{C}$ for $6 \mathrm{~h}$ and subsequently at room temperature for $4 \mathrm{~h}$ : Anti-caspase-3 antibody (1:500; cat. no. ab13847), anti-Bax antibody (1:1,000; cat. no. ab32503), anti-Bcl-2 antibody (1:1,000; cat. no. ab692), anti-p53 antibody (1:1,000; cat. no. ab26), anti-Beclin1 antibody (1:1,000; cat. no. ab62557), anti-LC3B antibody (1:1,000; cat. no. ab48394), anti-TWEAK antibody $(1: 1,000$; cat. no. ab37170), anti-p38 (phospho T180+Y182) antibody (1:1,000; cat. no. ab45381), anti-p38 antibody $(1: 1,000$; cat. no. ab31828), and anti-GAPDH antibody $(1: 2,000$; cat. no. ab8245; all Abcam). The horseradish peroxidase-conjugated secondary antibodies were goat anti-mouse IgG heavy and light chains (H\&L; 1:2,000; cat. no. ab6789) and donkey anti-goat IgG H\&L (1:2,000; cat. no. ab6885). The membranes were subsequently incubated at room temperature for $1 \mathrm{~h}$. GAPDH was used as the reference protein. Blots were visualized using enhanced chemiluminescence (Thermo Fisher Scientific, Inc.). The density of the blots was analyzed using Quantity One software version 2.4 (Bio-Rad Laboratories, Inc., Hercules, CA, USA).
Statistical analysis. The data were analyzed using Prism GraphPad version 6.0 software (GraphPad Software, Inc., La Jolla, CA, USA) and are presented as the mean \pm standard deviation. Comparisons of multiple treatment groups were conducted using one-way analysis of variance followed by Tukey's and Bonferroni's post-hoc tests. $\mathrm{P}<0.05$ was considered to indicate a statistically significant difference.

\section{Results}

MC3T3-E1 cells are successfully identified. Under the inverted microscope (x200), MC3T3-E1 cells were successfully observed in serum medium and by immunocytochemical staining following $24 \mathrm{~h}$ of culture (Fig. 1A).

Pretreatment with Hy increases viability of Ti particle-injured MC3T3-E1 cells. The CCK-8 assay results demonstrated a negative influence of Ti particles on the viability of MC3T3-E1 cells in a time- and concentration-dependent manner $(\mathrm{P}<0.05$; Fig. 1B). In groups that were pretreated with $\mathrm{Hy}$, cells were protected against Ti particle-induced injury and exhibited increased viability, compared with the Ti group $(\mathrm{P}<0.05$; Fig. $1 \mathrm{C})$.

Pretreatment with Hydecreases apoptosis in Tiparticle-injured MC3T3-E1 cells. Apoptosis rates in the control, Ti, Hy-1+Ti and $\mathrm{Hy}-2+\mathrm{Ti}$ groups were detected by FCM. In response to $\mathrm{Ti}$ particles, the apoptosis rate of MC3T3-E1 cells was significantly increased by $\sim 10$ times from $2.08 \pm 0.18 \%$ in the control group to $20.04 \pm 1.79 \%$ in the Ti group $(\mathrm{P}<0.01)$. The difference in apoptosis rates between the $\mathrm{Ti}$ and $\mathrm{Hy}-2+\mathrm{Ti}$ group was significant $(\mathrm{P}<0.05$; Fig. 2$)$.

Hy pretreatment mitigates autophagy of Ti particle injured MC3T3-E1 cells. The FCM results demonstrated alterations in autophagy rates of MC3T3-E1 cells in different conditions. In the Ti particles treated groups, autophagy was significantly increased, with an approximately four times increase from normal cells to Ti treated cells $(\mathrm{P}<0.01)$. In the Hy1+Ti and Hy2+Ti groups, Hy pretreatment mitigated the increase in autophagy in Ti particle-induced injury. Under the pretreatment condition of high dose of $\mathrm{Hy}$, the autophagy rate was significantly decreased by half $(\mathrm{P}<0.01)$. With the addition of protease inhibitors (E64d and pepstatin A; 1:1) in each group, autophagy rates were significantly blocked $(\mathrm{P}<0.05$; Fig. 3$)$.

Pretreatment with Hy downregulates the expression of pro-apoptotic genes in Ti particle-injured MC3T3-E1 cells. Using RT-qPCR and western blotting, alterations in the expression levels of apoptosis-associated gene products were detected among groups. It was observed that under treatment with Ti particles, the mRNA and protein expression levels of pro-apoptotic genes caspase-3, Bax and p53 were significantly increased, and the anti-apoptotic gene Bcl-2 was significantly decreased, compared with the control group $(\mathrm{P}<0.05$ or $\mathrm{P}<0.01)$. In the conditions with Hy pretreatment, the differences were not as pronounced. In particular, in the high-dose Hy group, the expression levels of caspase-3, Bax and p53 were significantly decreased; whereas the expression level of $\mathrm{Bcl}-2$ gene products was significantly upregulated compared with the Ti group $(\mathrm{P}<0.05$ or $\mathrm{P}<0.01$; Fig. $4 \mathrm{~A}-\mathrm{E})$. 
A

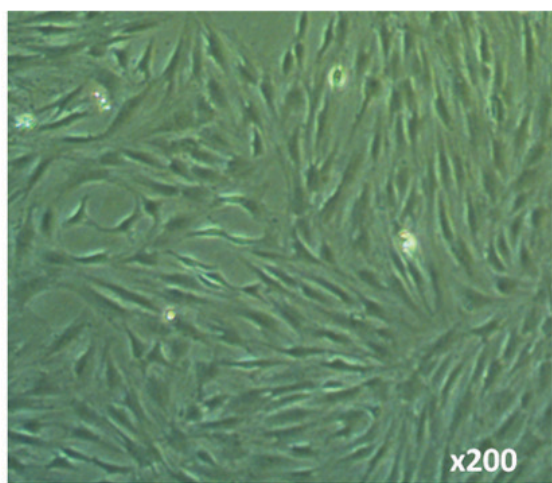

B

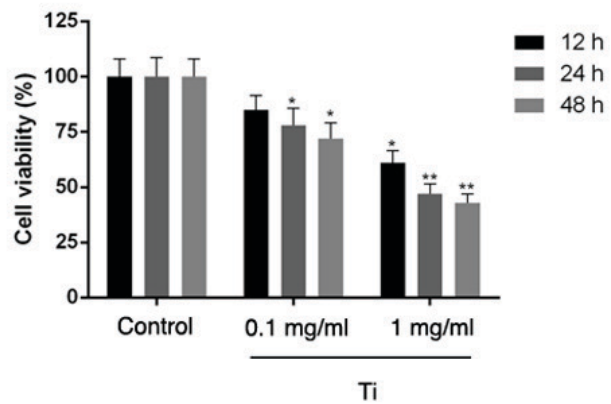

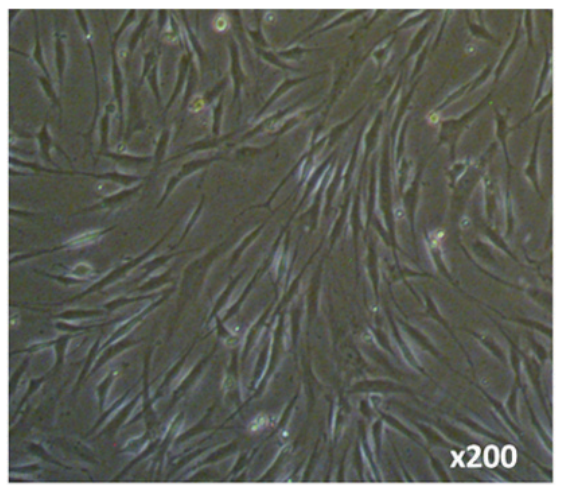

C

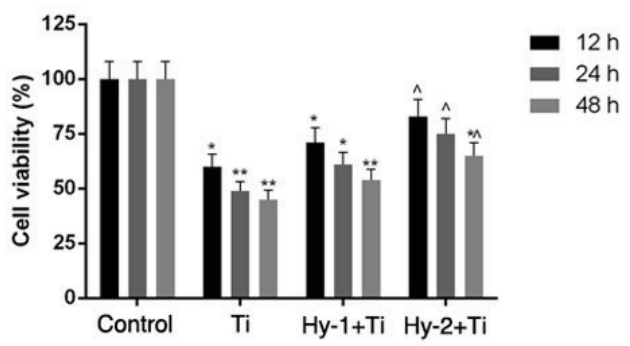

Figure 1. Cell viability of MC3T3-E1 cells is detected in the control group, Ti $(1 \mathrm{mg} / \mathrm{ml})$ group, Hy-1 (200 $\mu \mathrm{g} / \mathrm{ml})+\mathrm{Ti}$ group and Hy-2 (400 $\mu \mathrm{g} / \mathrm{ml})+\mathrm{Ti}$ group (A) MC3T3-E1 cells were successfully observed in serum medium (left) and via immunohistochemical staining (right) after $24 \mathrm{~h}$ culture under the microscope. (B) Ti particles inhibited cell viability in a time- and dose-dependent manner. (C) Pretreatment with Hy increased cell viability when treated with Ti. Data are presented as the mean \pm standard deviation. $\mathrm{n}=3 .{ }^{*} \mathrm{P}<0.05,{ }^{* *} \mathrm{P}<0.01$ vs. respective control group; ${ }^{\wedge} \mathrm{P}<0.05$ vs. respective $\mathrm{Ti}(1 \mathrm{mg} / \mathrm{ml}) \mathrm{group}$. Ti, titanium; Hy, hyperoside.
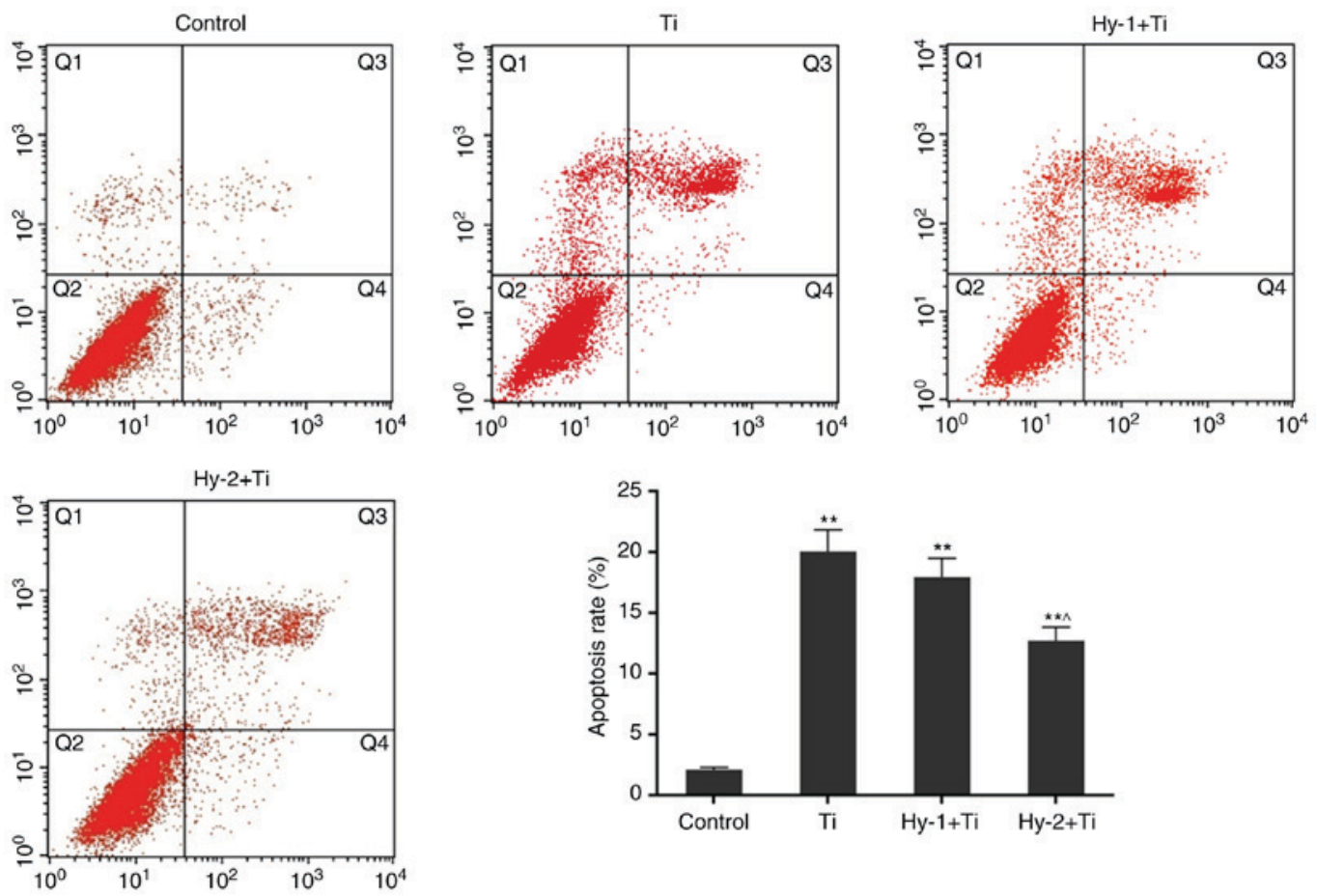

Figure 2. Apoptosis rates in the control, Ti $(1 \mathrm{mg} / \mathrm{ml}), \mathrm{Hy}-1(200 \mu \mathrm{g} / \mathrm{ml})+\mathrm{Ti}$ and $\mathrm{Hy}-2(400 \mu \mathrm{g} / \mathrm{ml})+\mathrm{Ti}$ groups are detected using flow cytometry. Pretreatment with Hy mitigated the apoptosis of Ti particle-injured MC3T3-E1 cells. Data are presented as the mean \pm standard deviation. $n=3$. ${ }^{* *} \mathrm{P}<0.01$ vs. control group; ${ }^{\wedge} \mathrm{P}<0.05$ vs. Ti group. Ti, titanium; Hy, hyperoside.

Pretreatment with Hy downregulates the expression of Beclinl and LC3-II/I in Ti particle-injured MC3T3-E1 cells. RT-qPCR and western blotting demonstrated that the autophagy-associated genes Beclin1 and LC3-II/I were highly expressed in Ti particle-injured cells, as there was a significant increase in the expression levels of their mRNA and proteins 


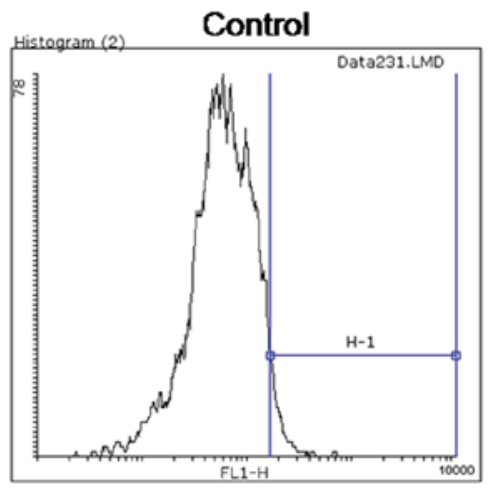

Ti+E64d+pepstatin A
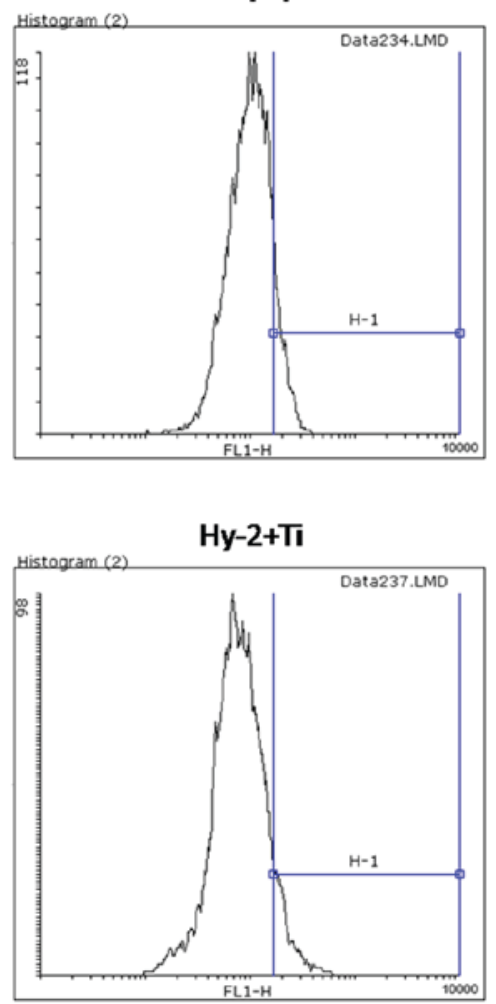

E64d+pepstatin A

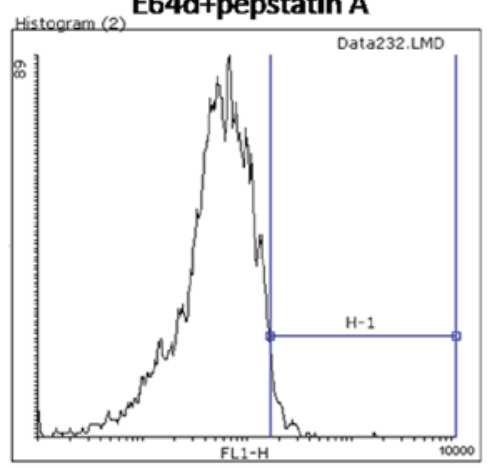

Hy-1+Tा

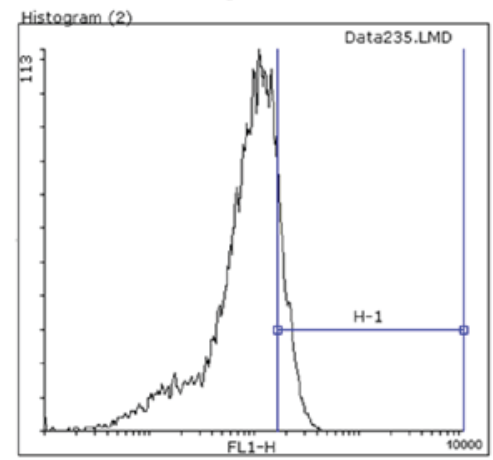

Hy-2+Ti+E64d+pepstatin A

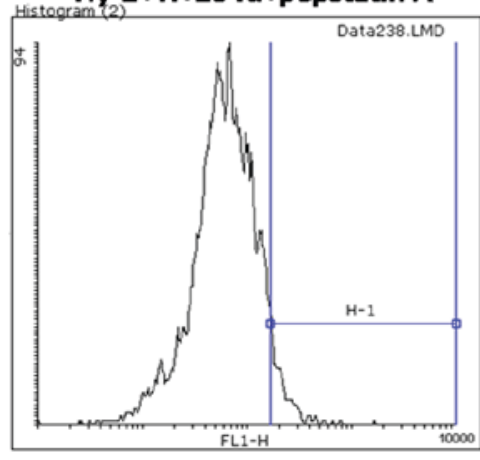

Ti

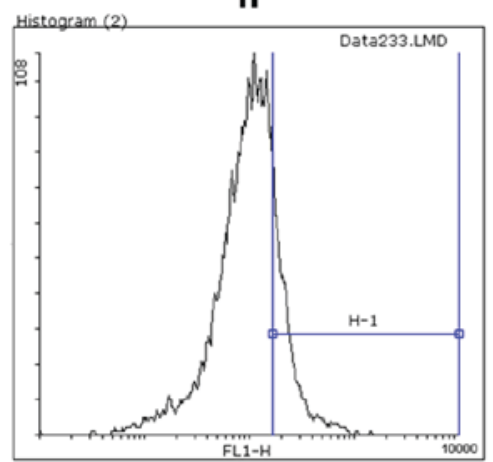

Hy-1+Ti+E64d+pepstatin A
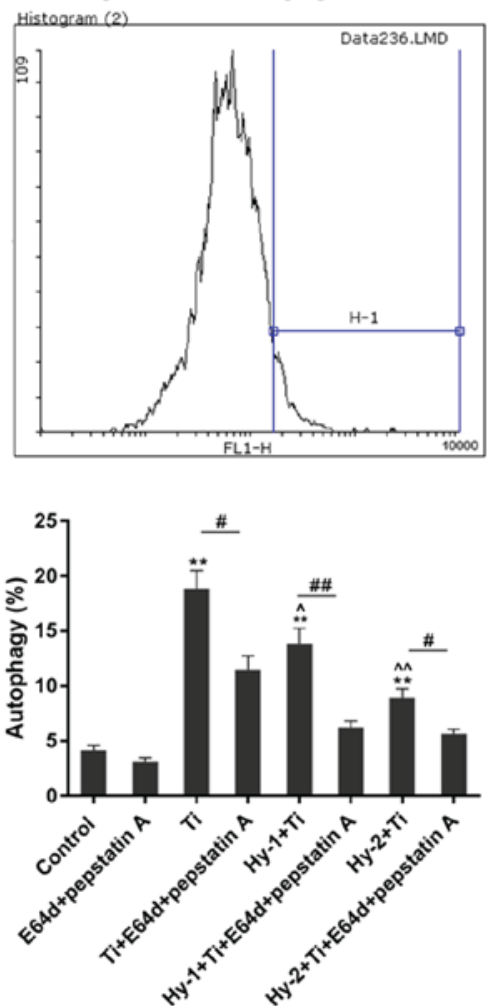

Figure 3. Autophagy rates in control,E64d+pepstain A (1:1), Ti, Ti+E64d+pepstain A Hy-1+Ti,Hy-1+Ti+E64d+pepstain A, Hy-2+Ti and Hy-2+Ti+E64d+pepstain A groups are detected using flow cytometry. Hy pretreatment mitigated autophagy of Ti particle injured MC3T3-E1 cells. Data are presented as the mean \pm standard deviation. $\mathrm{n}=3 .{ }^{* *} \mathrm{P}<0.01$ vs. control group; ${ }^{\wedge} \mathrm{P}<0.05,{ }^{\wedge} \mathrm{P}<0.01$ vs. Ti group; ${ }^{\#} \mathrm{P}<0.05,{ }^{\# \#} \mathrm{P}<0.01$. Ti, titanium; Hy, hyperoside.

compared with the control cells $(\mathrm{P}<0.05$ or $\mathrm{P}<0.01)$. In the $\mathrm{Ti}$ group, the protein expression levels of Beclin1 and LC3-II/I were approximately four and 15 times increased, respectively, in comparison with the control group $(\mathrm{P}<0.01)$. In Hy-pretreated cells, the expression levels of these two genes were decreased, and the effect of pretreatment with Hy on downregulating Beclin1 and LC3-II/I was demonstrated; a significant decrease in their protein expression levels compared with the Ti group was observed $(\mathrm{P}<0.05$ or $\mathrm{P}<0.01$; Fig. $4 \mathrm{~F}-\mathrm{H})$.

Pretreatment with Hy inhibits the activation of the TWEAK-p38 pathway in Ti particle-injured MC3T3-E1 cells. Detection of protein expression levels via western blotting revealed a significant alteration in the expression of the TWEAK-p38 pathway in the different conditions. Treatment with Ti particles significantly upregulated the expression of TWEAK and activated the phosphorylation of p38 by five and 15 times, respectively, compared with the control $(\mathrm{P}<0.01$; Fig. 5). In cells subjected to pretreatment with $\mathrm{Hy}$, the phosphorylation levels of the TWEAK-p38 pathway were decreased. There were significant differences in the Hy-pretreated groups compared with the Ti group $(\mathrm{P}<0.01$; Fig. 5).

TWEAK overexpression and p38MAPK activation elevates the rates of apoptosis and autophagy in Ti particle-injured MC3T3-E1 cells, even under pretreatment with Hy. Based on the aforementioned experiments, Ti particles induced high apoptosis and autophagy rates of MC3T3-E1 cells, and pretreatment with Hy may mitigate the injury with inhibited levels of TWEAK and p38 MAPK activation (Fig. 5B). To verify that the TWEAK and p38 MAPK signaling pathways are the mechanisms of action of pretreatment with Hy, TWEAK was overexpressed and the p38 MAPK pathway was activated. Apoptosis and autophagy rates were subsequently detected in 
A

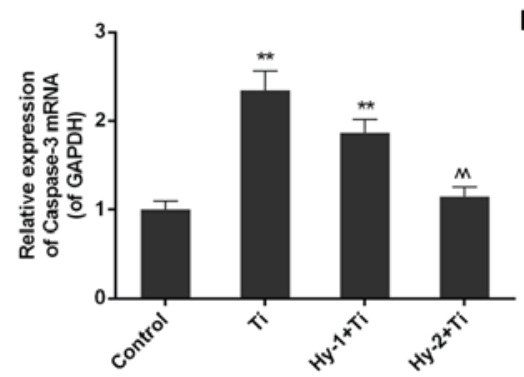

D
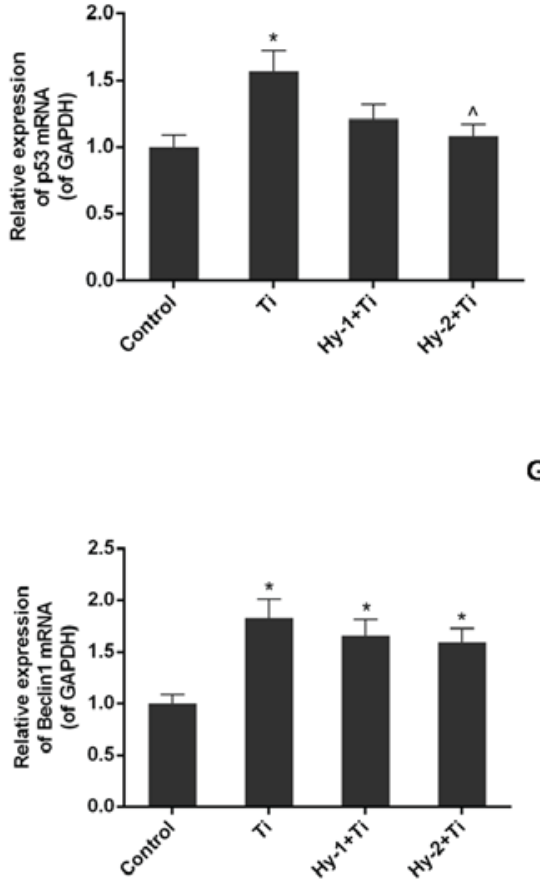

G

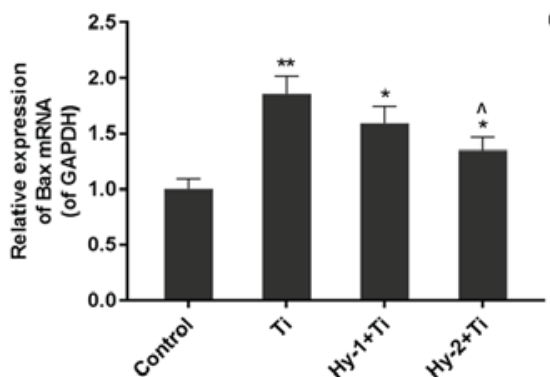

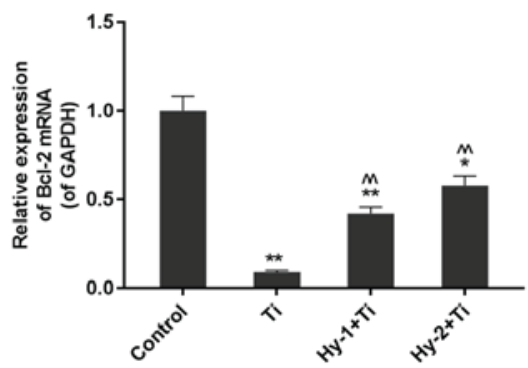

E
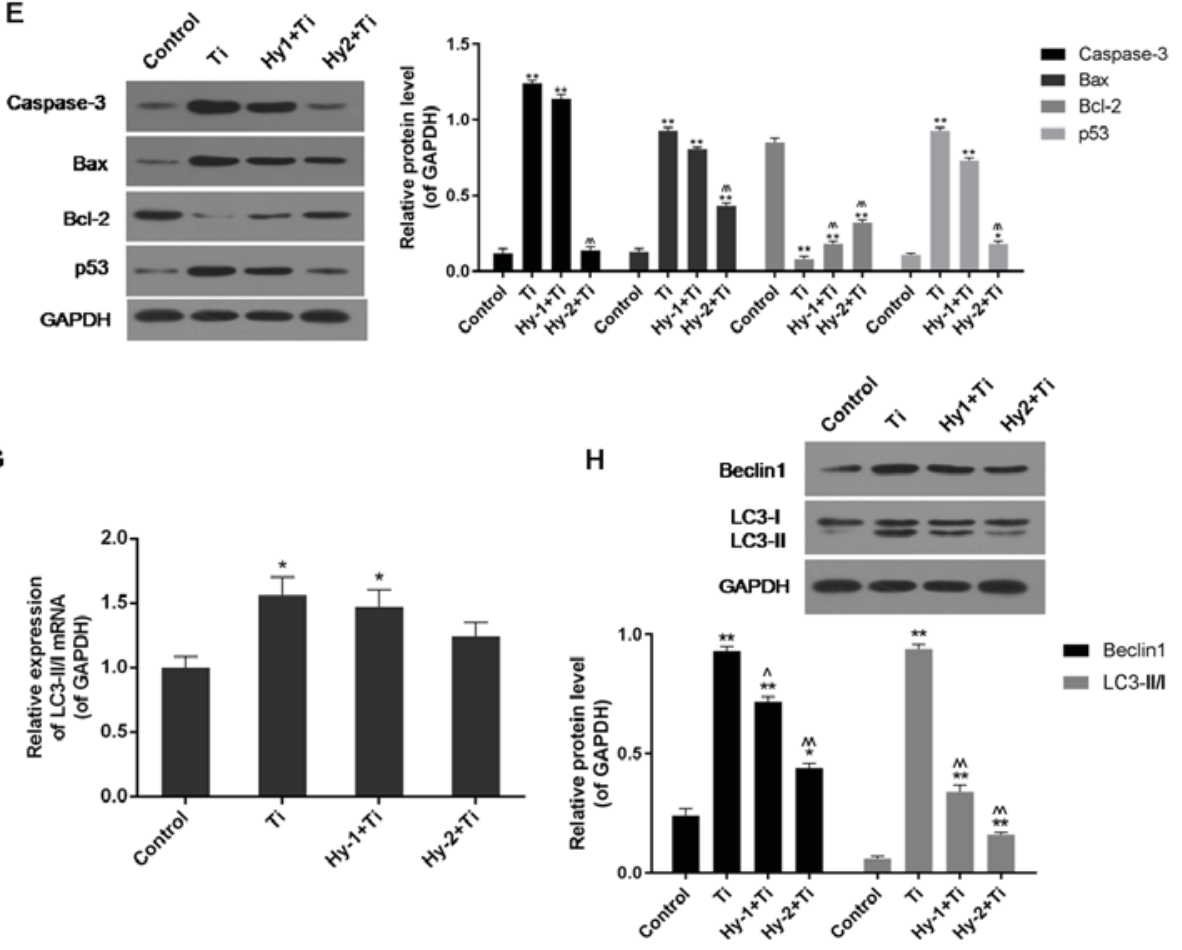

Figure 4. Expression levels of apoptosis and autophagy associated genes are detected by reverse transcription-quantitative polymerase chain reaction and western blotting in the control group, Ti $(1 \mathrm{mg} / \mathrm{ml})$ group, Hy-1 (200 $\mu \mathrm{g} / \mathrm{ml})+\mathrm{Ti}$ group and Hy-2 (400 $\mu \mathrm{g} / \mathrm{ml})+\mathrm{Ti}$ group. (A) Hy pretreatment downregulated expression of caspase-3 mRNA in Ti particle injured cells. (B) Hy pretreatment downregulated expression of Bax mRNA in Ti particle injured cells. (C) Hy pretreatment upregulated expression of Bcl-2 mRNA in Ti particle injured cells. (D) Hy pretreatment downregulated expression of p53 mRNA in Ti particle injured cells. (E) Hy pretreatment decreased protein expression levels of caspase-3, Bax and p53; however increased the expression level of Bcl-2 in Ti particle induced injury. (F) Hy pretreatment downregulated expression of Beclin1 mRNA in Ti particle injured cells. (G) Hy pretreatment downregulated the mRNA expression level of LC3-II/I in Ti particle injured cells. (H) Hy pretreatment decreased the protein expression level of Beclin1 and the ratio of LC3-II and LC3-I in Ti particle injured cells. Data are presented as mean \pm standard deviation. $\mathrm{n}=3$. ${ }^{*} \mathrm{P}<0.05$, ${ }^{* *} \mathrm{P}<0.01$ vs. control group; ${ }^{\wedge} \mathrm{P}<0.05$ and ${ }^{\wedge} \mathrm{P}<0.01$ vs. Ti $(1 \mathrm{mg} / \mathrm{ml})$ group. Ti, titanium; Hy, hyperoside; Bax, apoptosis regulator BAX; Bcl-2, apoptosis regulator Bcl-2; p53, cell tumor antigen p53; LC-II/I, microtubule-associated protein light chain 3 conversion LC3-II/I.

the Ti, Hy+Ti, TWEAK+Ti, TWEAK+Hy+Ti, Anisomycin+Ti and Anisomycin+Hy+Ti groups. The results suggested that TWEAK upregulation and p38 MAPK phosphorylation may increase the apoptosis and autophagy rates in Ti particle-injured cells, even with pretreatment with Hy (P<0.05; Fig. 6), which suggested that TWEAK and p38 MAPK may serve important roles in the protective actions of $\mathrm{Hy}$ in Ti particle-induced injury.

\section{Discussion}

In the present study, a reduction in cell viability was observed in MC3T3-E1 cells with the addition of Ti particles, and the inhibitory effect was exerted in a dose-dependent manner. In the condition with Ti particles, the apoptosis and autophagy rates of MC3T3-E1 cells were significantly increased. Pretreatment with Hy, a flavonoid glycoside compound extracted from natural plants, was demonstrated to mitigate apoptosis and autophagy in MC3T3-E1 cells in Ti particle-induced injury, revealing its potential protective effect on osteoblasts.

The stability of bone structure relies on the dynamic equilibrium of osteolysis and osteogenesis; any factor which activates osteoclasts or inhibits osteoblasts may directly or indirectly disturb the balance, resulting in loss of bone mass $(25,26)$. Numerous previous studies have demonstrated that wear particles stimulate cells around a prosthesis to release cytokines, including IL-6, IL-8 and TNF- $\alpha$, to affect the viability, proliferation, phenotype and function of osteoblasts, resulting in periprosthetical osteolysis and prosthetic loosening (27-30).

Previous studies demonstrated that various apoptotic macrophages, foreign body giant cells and T lymphocytes, in addition to highly expressed caspase-3, Bax and p53 were detected in interface membranes between a prosthesis and the 
A

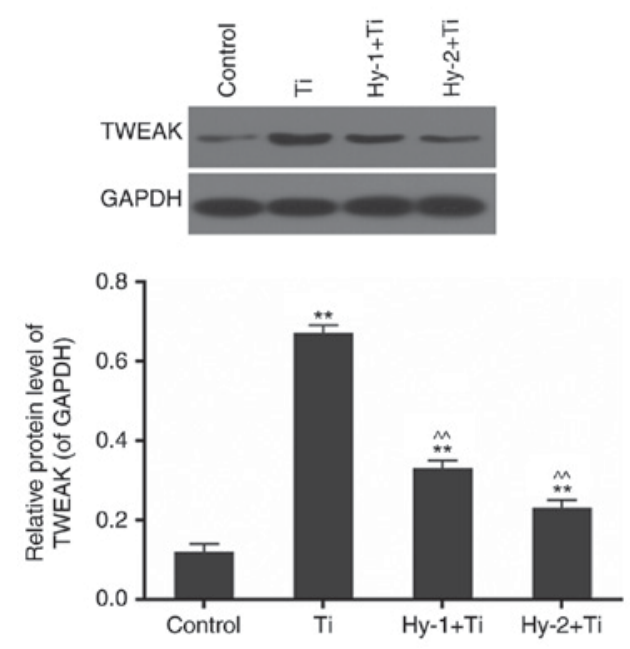

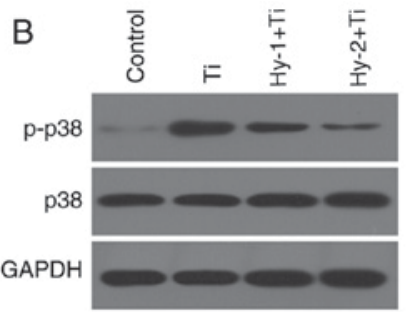

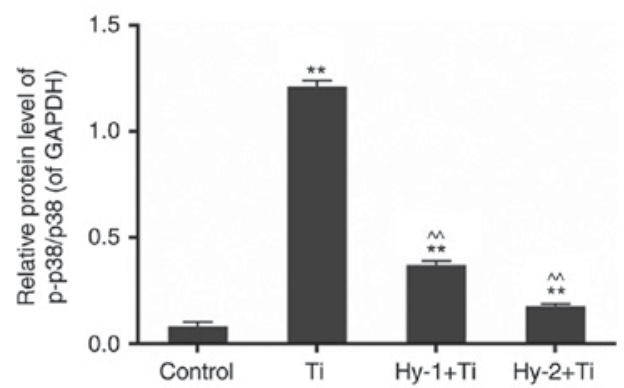

Figure 5. Protein expression levels of TWEAK and the p38MAPK pathway are analyzed by western blotting in the control group, Ti (1 mg/ml) group, Hy-1 $(200 \mu \mathrm{g} / \mathrm{ml})+$ Ti group and Hy-2 $(400 \mu \mathrm{g} / \mathrm{ml})+$ Ti group. (A) Pretreatment with Hy inhibited the activation of TWEAK in MC3T3-E1 cells in Ti particle-induced injury. (B) Pretreatment with Hy inhibited the phosphorylation of p38 MAPK in MC3T3-E1 cells in Ti particle-induced injury. Data are presented as the mean \pm standard deviation. $\mathrm{n}=3$. ${ }^{* *} \mathrm{P}<0.01$ vs. control group; ${ }^{\wedge} \mathrm{P}<0.01$ vs. Ti $(1 \mathrm{mg} / \mathrm{ml})$ group. TWEAK, tumor necrosis factor ligand superfamily member 12 ; p38, mitogen activated protein kinase 11; p-p38, phosphorylated p38; MAPK, mitogen activated protein kinase; Ti, titanium; Hy, hyperoside.
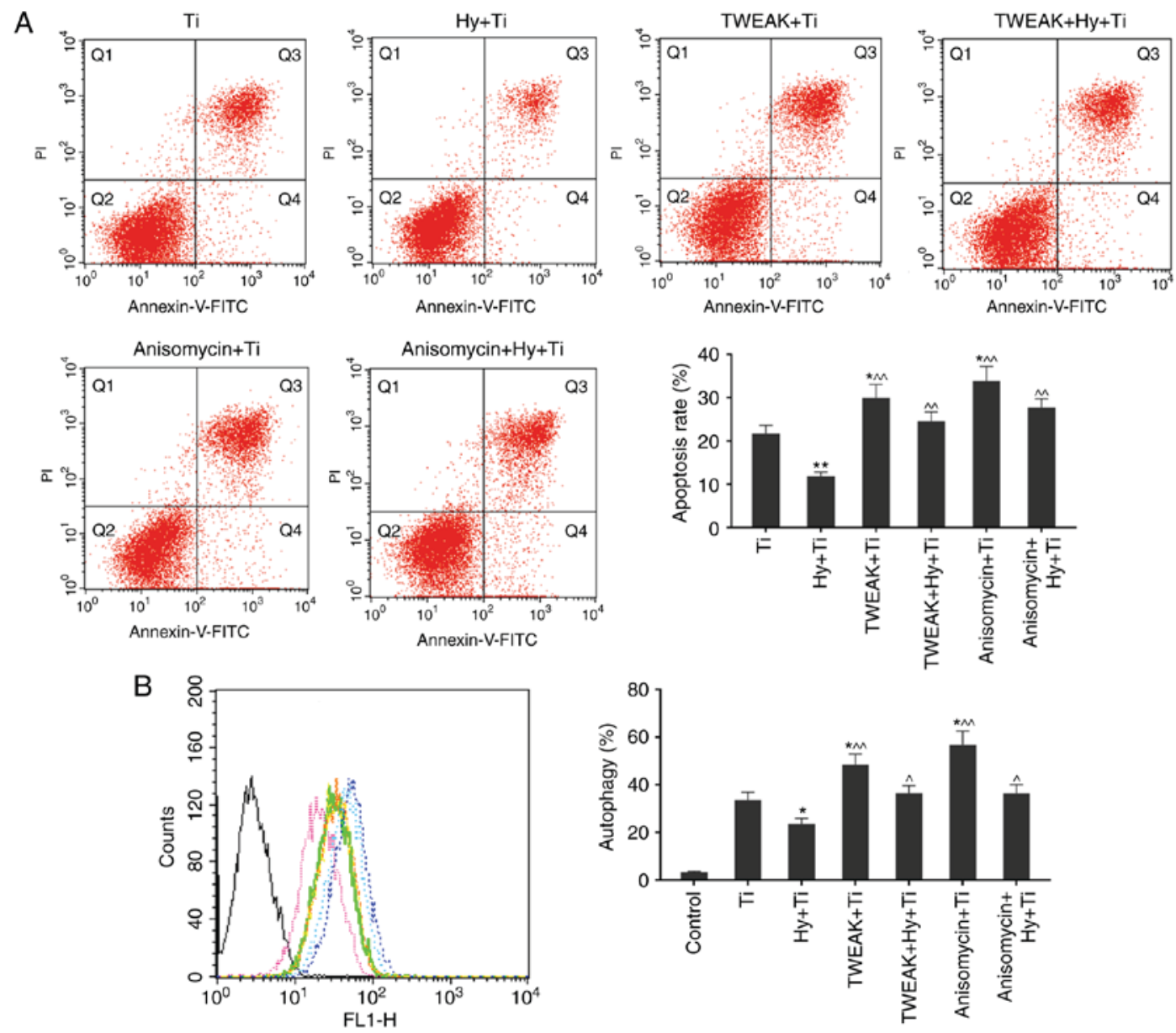

Figure 6. Apoptosis and autophagy rates in Ti, $\mathrm{Hy}(400 \mu \mathrm{g} / \mathrm{ml})+\mathrm{Ti}$, TWEAK+Ti, TWEAK+Hy+Ti, Anisomycin+Ti and Anisomycin+Hy+Ti groups are determined using flow cytometry. (A) TWEAK overexpression and p38 MAPK activation by anisomycin were able to elevate the apoptosis rate in Ti particle-injured cells, even under Hy pretreatment. (B) TWEAK overexpression and p38 MAPK activation by anisomycin may enhance the autophagy rate in Ti particle-injured cells, even under pretreatment with Hy condition. Black, control; green, Ti; pink, Hy+Ti; light blue, TWEAK+Ti; yellow, TWEAK+Hy+Ti; blue, Anisomycin+Ti; orange, Anisomycin+Hy+Ti. Data are presented as the mean \pm standard deviation. $\mathrm{n}=3 .{ }^{*} \mathrm{P}<0.05,{ }^{* *} \mathrm{P}<0.01$ vs. Ti group; ${ }^{\wedge} \mathrm{P}<0.05,{ }^{\wedge} \mathrm{P}<0.01 \mathrm{vs}$. Hy+Ti group. Ti, titanium; Hy, hyperoside; TWEAK, tumor necrosis factor ligand superfamily member 12; p38, mitogen activated protein kinase 11; MAPK, mitogen activated protein kinase; FITC, fluorescein isothiocyanate; PI, propidium iodide. 
joint $(30,31)$. It was observed that the regulation of caspase-3 expression and apoptosis was closely implicated in the local accumulation of wear particles and osteolysis $(31,32)$. Excessive autophagy may additionally activate apoptosis or convert itself to autophagic death, although initial autophagy inhibits oxidative stress injury to protect the cell (33-36). Autophagy, which serves a key role in cell stress and environmental adaptation, is strongly associated with cell damage repair, replication and proliferation (37). Stimulatory factors, including glucocorticoid and monosodium urate monohydrate, were demonstrated to induce autophagy in osteoblasts or osteocytes (37-39).

In the process of cellular apoptosis, caspase-3, a primary cleavage enzyme and a reliable marker in the mammalian apoptotic and inflammatory pathways, is activated by regulating caspase- 9 and/or caspase- 8 in the mitochondrial pathway and/or the death receptor-mediated pathway to induce cellular apoptosis (40-42). The anti-apoptotic gene Bcl-2 and the pro-apoptotic gene Bax are two key apoptosis-associated genes (43). When cells are stimulated via death signals, pro-apoptotic proteins will undergo a conformational change, transposition from the cytoplasm to membranes of organelles and reaction with anti-apoptotic proteins, thus reversing their inhibitory effect on apoptosis and releasing a series of pro-apoptotic factors, eventually resulting in apoptosis $(44,45)$. p53, located at chromosome 17q13.1, is a cancer suppressor gene with a strong association with tumors (46). p53 is a transcription factor at the convergence of numerous cellular stress pathways, including oncogene activation, hypoxia, DNA damage and endoplasmic reticulum stress, to induce different biological cell responses, including cell cycle arrest at the $G_{1}$ or $G_{2}$ phases, DNA repair, senescence or even apoptosis $(47,48)$. In the present study, high expression levels of the pro-apoptotic genescaspase-3, Bax and p53 were observed, with a decreased expression level of the anti-apoptotic gene Bcl-2 in the Ti model group and an increased apoptosis rate compared with normal cells. Pretreatment with Hy markedly downregulated the expression levels of pro-apoptotic genes and upregulated the expression level of Bcl-2 in the Ti injury model, and the effect was exerted in a concentration-dependent manner, which suggested a protective effect of $\mathrm{Hy}$ on Ti particle-induced apoptosis.

Autophagy is an important mechanism for the self-protection of cells through lysosomes, which assist cells in maintaining the cellular synthesis, degradation and progression cycle to promote cell survival (37). However, excessive autophagy induces apoptosis $(35,49)$. BECN1 and LC3 are two autophagy regulatory genes involved in the formation of autophagosomes. Beclin1 is a protein that in humans is encoded by the BECN1 gene, which regulates autophagy by combining with phosphatidylinositol 3 kinase and regulating ubiquitin-like modifier-activating enzyme proteins $(50,51)$. The BECN-1 gene is essential for the maintenance of homeostasis, cell development and differentiation, tumorigenesis and cellular adaptation (52). LC3, divided into LC3-I and LC3-II, is able to target to the membrane of autophagosomes. Generally, LC3-I is regularly expressed in the cytoplasm and once autophagy occurs, LC3-I combines with phosphatidyl ethanolamine in the process of modification to form LC3-II (53). The LC3-II content is positively correlated with the number of autophagic vacuoles (54). Along with alterations in the autophagy rate under different conditions of $\mathrm{Ti}$ particles and Hy, consistent expression levels of Beclin1 and LC3-II/Iin MC3T3-E1 cells were observed. Upon the addition of Ti particles, the expression levels of Beclin1 and LC3-II/I were significantly upregulated to promote autophagy. Upon pretreatment with $\mathrm{Hy}$, these protein expression levels were decreased.

Numerousimmunecells, including monocyte-macrophages, dendritic cells and activated $\mathrm{T}$ cells, are able to generate soluble forms of cytokines (55-57). Upon inflammation or tissue injury, the expression of TWEAK may be significantly upregulated $(14,15)$. Phosphorylation activates MAPKs, and the signal transmission of MAPK pathways is fulfilled by the continuous phosphorylation of downstream substrates (58). p38 MAPK is a classical MAPK pathway. The cascade reaction of p38MAPK includes four kinases, p21-activated kinase, mixed lineage kinase, MKK3/6/4 and p38MAPK, which constitute a continuous reaction chain of protein kinases (20-22). With further research on MAPK, an increasing number of studies reported that the p38MAPK signal pathway served an important role in inflammatory osteolysis, including osteoarthritis and chronic infectious arthritis (20-22). Previously, a number of studies suggested that the p38 MAPK pathway serves a role in the pathological process of inflammatory osteolysis induced by particles; however, how the proteins are expressed in the interface membrane of prosthetic loosening following artificial joint replacement remains controversial $(59,60)$. Whether TWEAK is involved in periprosthetical osteolysis is unclear $(61,62)$. In the present study, the protein expression level of TWEAK was significantly increased in the Ti model cells in comparison with the control group. Furthermore, the increasing ratio of p-p38 and p38, suggesting a higher phosphorylation level of p38 MAPK, was detected. Pretreatment with Hy of MC3T3-E1 cells in Ti-induced injury was observed to mitigate the alterations in the activation of p-p38 and TWEAK. In cells that had undergone pretreatment with $\mathrm{Hy}$, the expression of TWEAK was downregulated, and the p-p38/p38 expression level was decreased in the Hy-1+Ti and Hy-2+Ti group.

It was demonstrated that pretreatment with Hy may be able to improve cell viability and proliferation, and decrease apoptosis and autophagy to protect MC3T3-E1 cells from Ti particle-induced damage. The TWEAK and p38 pathways may be activated to contribute to the repair processes. Hy protected osteoblasts against Ti particle-induced damage by regulating the TWEAK-p38 pathway. The present results suggested that Hy has the potential to function as a protective agent for osteoblasts; however, further studies on the underlying mechanism are required.

\section{Acknowledgements}

Not applicable.

\section{Funding}

No funding was received.

\section{Availability of data and materials}

The datasets used and/or analyzed during the current study are available from the corresponding author on reasonable request. 


\section{Authors' contributions}

X-FZ conceived and designed the study. QZ performed the experiments, analyzed the data and was the primary contributor in writing the manuscript. All authors read and approved the final manuscript.

\section{Ethics approval and consent to participate}

The present study was approved by the Ethics Committee of Huai'an Second People's Hospital (Huai'an, China) and the Affiliated Huai'an Hospital of Xuzhou Medical University (Huai'an, China).

\section{Patient consent for publication}

Not applicable.

\section{Competing interests}

The authors declare that they have no competing interests.

\section{References}

1. Amirhosseini M, Andersson G, Aspenberg P and Fahlgren A Mechanical instability and titanium particles induce similar transcriptomic changes in a rat model for periprosthetic osteolysis and aseptic loosening. Bone Rep 7: 17-25, 2017.

2. Haynes DR, Crotti TN and Zreiqat H: Regulation of osteoclast activity in peri-implant tissues. Biomaterials 25: 4877-4885, 2004.

3. Lochner K, Fritsche A, Jonitz A, Hansmann D, Mueller P, Mueller-Hilke B and Bader R: The potential role of human osteoblasts for periprosthetic osteolysis following exposure to wear particles. Int J Mol Med 28: 1055-1063, 2011.

4. Piao MJ, Kang KA, Zhang R, Ko DO, Wang ZH, You HJ, Kim HS, Kim JS, Kang SS and Hyun JW: Hyperoside prevents oxidative damage induced by hydrogen peroxide in lung fibroblast cells via an antioxidant effect. Biochim Biophys Acta 1780: 1448-1457, 2008

5. Zhang XN, Li JM, Yang Q, Feng B, Liu SB, Xu ZH, Guo YY and Zhao MG: Anti-apoptotic effects of hyperoside via inhibition of NR2B-containing NMDA receptors. Pharmacol Rep 62: 949-955, 2010.

6. Choi JH, Kim DW, Yun N, Choi JS, Islam MN, Kim YS and Lee SM: Protective effects of hyperoside against carbon tetrachloride-induced liver damage in mice. J Nat Prod 74: 1055-1060, 2011.

7. Haas JS, Stolz ED, Betti AH, Stein AC, Schripsema J, Poser GL and Rates SM: The anti-immobility effect of hyperoside on the forced swimming test in rats is mediated by the D2-like receptors activation. Planta Med 77: 334-339, 2011.

8. Ku SK, Kwak S, Kwon OJ and Bae JS: Hyperoside inhibits high-glucose-induced vascular inflammation in vitro and in vivo. Inflammation 37: 1389-1400, 2014.

9. Li W, Liu M, Xu YF, Feng Y, Che JP, Wang GC and Zheng JH: Combination of quercetin and hyperoside has anticancer effects on renal cancer cells through inhibition of oncogenic microRNA-27a. Oncol Rep 31: 117-124, 2014.

10. Zhang $Y$, Wang $M$, Dong $H$, Yu $X$ and Zhang $J$ : Anti-hypoglycemic and hepatocyte-protective effects of hyperoside from Zanthoxylum bungeanum leaves in mice with high-carbohydrate/high-fat diet and alloxan-induced diabetes. Int J Mol Med 41: 77-86, 2018.

11. Liu Q, Xiao S and Xia Y: TWEAK/Fn14 activation participates in skin inflammation. Mediators Inflamm 2017: 6746870, 2017.

12. Tallroth K, Eskola A, Santavirta S, Konttinen YT and Lindholm TS: Aggressive granulomatous lesions after hip arthroplasty. J Bone Joint Surg Br 71: 571-575, 1989.

13. Harris WH: Osteolysis and particle disease in hip replacement. A review. Acta Orthop Scand 65: 113-123, 1994.

14. Santavirta S, Takagi M, Gomez-Barrena E, Nevalainen J, Lassus J, Salo J and Konttinen YT: Studies of host response to orthopedic implants and biomaterials. J Long Term Eff Med Implants 9: 67-76, 1999
15. Knowles HJ and Athanasou NA: Acute hypoxia and osteoclast activity: A balance between enhanced resorption and increased apoptosis. J Pathol 218: 256-264, 2009.

16. Schmalzried TP, Jasty M and Harris WH: Periprosthetic bone loss in total hip arthroplasty. Polyethylene wear debris and the concept of the effective joint space. J Bone Joint Surg Am 74: 849-863, 1992.

17. Wataha JC: Predicting clinical biological responses to dental materials. Dent Mater 28: 23-40, 2012.

18. Cooper HJ, Ranawat AS, Potter HG, Foo LF, Koob TW and Ranawat CS: Early reactive synovitis and osteolysis after total hip arthroplasty. Clin Orthop Relat Res 468: 3278-3285, 2010.

19. Matzinger P: Tolerance, danger, and the extended family. Annu Rev Immunol 12: 991-1045, 1994.

20. Konttinen Y, Imai S and Suda A: Neuropeptides and the puzzle of bone remodeling. State of the art. Acta Orthop Scand 67: 632-639, 1996.

21. King KY and Goodell MA: Inflammatory modulation of HSCs: Viewing the HSC as a foundation for the immune response. Nat Rev Immunol 11: 685-692, 2011.

22. Murray PJ and Wynn TA: Protective and pathogenic functions of macrophage subsets. Nat Rev Immunol 11: 723-737, 2011.

23. Lee YH, Cheng FY, Chiu HW, Tsai JC, Fang CY, Chen CW and Wang YJ: Cytotoxicity, oxidative stress, apoptosis and the autophagic effects of silver nanoparticles in mouse embryonic fibroblasts. Biomaterials 35: 4706-4715, 2014.

24. Livak KJ and Schmittgen TD: Analysis of relative gene expression data using real-time quantitative PCR and the 2(-Delta Delta C(T)) method. Methods 25: 402-408, 2001.

25. Buckley CD: Why does chronic inflammation persist: An unexpected role for fibroblasts. Immunol Lett 138: 12-14, 2011.

26. Nathan C and Ding A: Nonresolving inflammation. Cell 140: 871-882, 2010.

27. Vermes C, Chandrasekaran R, Jacobs JJ, Galante JO, Roebuck KA and Glant TT: The effects of particulate wear debris, cytokines, and growth factors on the functions of MG-63 osteoblasts. J Bone Joint Surg Am 83-A: 201-211, 2001.

28. Fritz EA, Glant TT, Vermes C, Jacobs JJ and Roebuck KA: Titanium particles induce the immediate early stress responsive chemokines IL-8 and MCP-1 in osteoblasts. J Orthop Res 20: 490-498, 2002.

29. Kusano K, Miyaura C, Inada M, Tamura T, Ito A, Nagase H, Kamoi $\mathrm{K}$ and Suda T: Regulation of matrix metalloproteinases (MMP-2, -3, -9, and -13) by interleukin-1 and interleukin-6 in mouse calvaria: Association of MMP induction with bone resorption. Endocrinology 139: 1338-1345, 1998.

30. Takei H, Pioletti DP, Kwon SY and Sung KL: Combined effect of titanium particles and TNF-alpha on the production of IL-6 by osteoblast-like cells. J Biomed Mater Res 52: 382-387, 2000.

31. Landgraeber S, von Knoch M, Löer F, Wegner A, Tsokos M, Hussmann B and Totsch M: Extrinsic and intrinsic pathways of apoptosis in aseptic loosening after total hip replacement. Biomaterials 29: 3444-3450, 2008

32. Huk OL, Zukor DJ, Ralston W, Lisbona A and Petit A: Apoptosis in interface membranes of aseptically loose total hip arthroplasty. J Mater Sci Mater Med 12: 653-658, 2001.

33. Cho DH, Jo YK, Hwang JJ, Lee YM, Roh SA and Kim JC: Caspase-mediated cleavage of ATG6/Beclin-1 links apoptosis to autophagy in HeLa cells. Cancer Lett 274: 95-100, 2009.

34. Yoo BH, Wu X, Derouet M, Haniff M, Eskelinen EL and Rosen K: Hypoxia-induced downregulation of autophagy mediator Beclin 1 reduces the susceptibility of malignant intestinal epithelial cells to hypoxia-dependent apoptosis. Autophagy 5: 1166-1179, 2009.

35. She C, Zhu LQ, Zhen YF, Wang XD and Dong QR: Activation of AMPK protects against hydrogen peroxide-induced osteoblast apoptosis through autophagy induction and NADPH maintenance: New implications for osteonecrosis treatment? Cell Signal 26: 1-8, 2014.

36. Lai EH, Hong CY, Kok SH, Hou KL, Chao LH, Lin LD, Chen MH, Wu PH and Lin SK: Simvastatin alleviates the progression of periapical lesions by modulating autophagy and apoptosis in osteoblasts. J Endod 38: 757-763, 2012.

37. Allaeys I, Marceau F and Poubelle PE: NLRP3 promotes autophagy of urate crystals phagocytized by human osteoblasts. Arthritis Res Ther 15: R176, 2013.

38. Xia X, Kar R, Gluhak-Heinrich J, Yao W, Lane NE, Bonewald LF, Biswas SK, Lo WK and Jiang JX: Glucocorticoid-induced autophagy in osteocytes. J Bone Miner Res 25: 2479-2488, 2010 . 
39. Jia J, Yao W, Guan M, Dai W, Shahnazari M, Kar R, Bonewald L, Jiang JX and Lane NE: Glucocorticoid dose determines osteocyte cell fate. FASEB J 25: 3366-3376, 2011.

40. Colell A, Ricci JE, Tait S, Milasta S, Maurer U, Bouchier-Hayes L, Fitzgerald P, Guio-Carrion A, Waterhouse NJ, Li CW, et al: GAPDH and autophagy preserve survival after apoptotic cytochrome c release in the absence of caspase activation. Cell 129: 983-997, 2007.

41. Zhang C, Yu H, Shen Y,Ni X, Shen S and Das UN: Polyunsaturated fatty acids trigger apoptosis of colon cancer cells through a mitochondrial pathway. Arch Med Sci 11: 1081-1094, 2015.

42. Kertmen H, Gurer B, Yilmaz ER, Kanat MA, Arikok AT, Ergüder BI, Hasturk AE, Ergil J and Sekerci Z: Antioxidant and antiapoptotic effects of darbepoetin- $\alpha$ against traumatic brain injury in rats. Arch Med Sci 11: 1119-1128, 2015.

43. Schendel SL and Reed JC: Measuring pore formation by Bcl-2 family proteins. Methods Enzymol 322: 274-282, 2000.

44. Shimizu S, Narita M and Tsujimoto Y: Bcl-2 family proteins regulate the release of apoptogenic cytochrome $\mathrm{c}$ by the mitochondrial channel VDAC. Nature 399: 483-487, 1999.

45. Kubicka-Sierszen A and Grzegorczyk JŁ: The influence of infectious factors on dendritic cell apoptosis. Arch Med Sci 11: 1044-1051, 2015.

46. Lauwers GY, Wahl SJ, Melamed J and Rojas-Corona RR: p53 expression in precancerous gastric lesions: An immunohistochemical study of PAb 1801 monoclonal antibody on adenomatous and hyperplastic gastric polyps. Am J Gastroenterol 88: 1916-1919, 1993.

47. Yue Y, Yang Y, Shi L and Wang Z: Suppression of human hepatocellular cancer cell proliferation by Brucea javanica oil-loaded liposomes via induction of apoptosis. Arch Med Sci 11: 856-862, 2015.

48. Olivares-Illana V and Fahraeus R: p53 isoforms gain functions. Oncogene 29: 5113-5119, 2010

49. Chen Y, McMillan-Ward E, Kong J, Israels SJ and Gibson SB Oxidative stress induces autophagic cell death independent of apoptosis in transformed and cancer cells. Cell Death Differ 15: $171-182,2008$

50. Tassa A, Roux MP, Attaix D and Bechet DM: Class III phosphoinositide 3-kinase--Beclin1 complex mediates the amino acid-dependent regulation of autophagy in $\mathrm{C} 2 \mathrm{C} 12$ myotubes. Biochem J 376: 577-586, 2003.

51. Liang XH, Kleeman LK, Jiang HH, Gordon G, Goldman JE, Berry G, Herman B and Levine B: Protection against fatal Sindbis virus encephalitis by beclin, a novel Bcl-2-interacting protein. J Virol 72: 8586-8596, 1998.
52. Arsov I, Li X, Matthews G, Coradin J, Hartmann B, Simon AK, Sealfon SC and Yue Z: BAC-mediated transgenic expression of fluorescent autophagic protein Beclin 1 reveals a role for Beclin 1 in lymphocyte development. Cell Death Differ 15: 1385-1395, 2008.

53. Li R, Ma M, Li L, Zhao L, Zhang T, Gao X, Zhang D, Zhu Y, Peng Q, Luo X and Wang M: The protective effect of autophagy on DNA damage in mouse spermatocyte-derived cells exposed to $1800 \mathrm{MHz}$ radiofrequency electromagnetic fields. Cell Physiol Biochem 48: 29-41, 2018.

54. Mizushima N: Methods for monitoring autophagy. Int J Biochem Cell Biol 36: 2491-2502, 2004.

55. Konttinen YT, Zhao D, Beklen A, Ma G, Takagi M, Kivelä-Rajamäki M, Ashammakhi N and Santavirta S: The microenvironment around total hip replacement prostheses. Clin Orthop Relat Res: 28-38, 2005

56. Ren PG, Irani A, Huang Z, Ma T, Biswal S and Goodman SB: Continuous infusion of UHMWPE particles induces increased bone macrophages and osteolysis. Clin Orthop Relat Res 469: 113-122, 2011.

57. Gallo J, Raska M, Mrázek F and Petrek M: Bone remodeling, particle disease and individual susceptibility to periprosthetic osteolysis. Physiol Res 57: 339-349, 2008.

58. Gross TS, King KA, Rabaia NA, Pathare P and Srinivasan S: Upregulation of osteopontin by osteocytes deprived of mechanical loading or oxygen. J Bone Miner Res 20: 250-256, 2005.

59. Chen D, Guo Y, Mao X and Zhang X: Inhibition of p38 mitogen-activated protein kinase down-regulates the inflammatory osteolysis response to titanium particles in a murine osteolysis model. Inflammation 35: 1798-1806, 2012.

60. Iwata Y, Wada T, Furuichi K, Sakai N, Matsushima K, Yokoyama H and Kobayashi K: p38 Mitogen-activated protein kinase contributes to autoimmune renal injury in MRL-Fas lpr mice. J Am Soc Nephrol 14: 57-67, 2003.

61. Zhang L, Bao D, Li P, Lu Z, Pang L, Chen Z, Guo H, Gao Z and Jin Q: Particle-induced SIRT1 downregulation promotes osteoclastogenesis and osteolysis through ER stress regulation. Biomed Pharmacother 104: 300-306, 2018.

62. Feng W, Li J, Liao S, Ma S, Li F, Zhong C, Li G, Wei Y, Huang H, Wei Q, et al: Gö6983 attenuates titanium particle-induced osteolysis and RANKL mediated osteoclastogenesis through the suppression of NFKB/JNK/p38 pathways. Biochem Biophys Res Commun 503: 62-70, 2018.

(i) $($ This work is licensed under a Creative Commons cc) Attribution-NonCommercial-NoDerivatives 4.0 International (CC BY-NC-ND 4.0) License. 